\title{
28. SHIPBOARD MEASUREMENTS OF SEISMIC VELOCITY, DENSITY, AND POROSITY IN DSDP LEG 46 BASALTS
}

\author{
Drummond Matthews, Department of Geodesy and Geophysics, University of Cambridge, England
}

\section{INTRODUCTION AND SUMMARY}

This paper is intended to preserve all that is of general interest from a more detailed account of physical properties written for the shipboard report. The measurements described here were undertaken in the hope that they would be relevant to the results of the Oblique Seismic Experiment and interest in them waned when damage to the ship made it impossible to carry out that experiment. The compressional wave velocities $\left(\mathrm{V}_{p}\right)$ obtained are summarized in Figure 1. They fall comfortably within the normal range of similar laboratory measurements made on submarine lavas and show the usual approximately linear relations to density and porosity. There was no evidence of consistent anisotropy. The calculated grain densities enable these basalts to be divided into two groups and the divisions correspond with divisions based on lithology and chemistry. Because specimens for laboratory measurements must be drilled from blocks that are not cracked, and because the measurements are made with high frequency sound, it is not safe to assert that the histogram of Figure 1 necessarily represents the velocities with which seismic waves would traverse the lava pile.

\section{METHOD AND ACCURACY}

Specimens were chosen by eye as soon as the cores were in the laboratory in order, so far as possible, to span the whole range of velocity, density, and porosity in the saturated rocks. The chosen specimens were kept under salt water until the measurements were made. We cut a one-inch-diameter minicore from each specimen and marked its orientation, utilizing the three axes $z$ downwards into the earth parallel with the drill axis, and $x$ and $y$ horizontal, for three perpendicular measurements of seismic velocity. After the velocities had been measured, the wet minicores were weighed in deionized water, weighed in air, dried, and weighed again . From the weighings the porosity, wet bulk density, and grain density were calculated. The drying was done at $70^{\circ} \mathrm{C}$ in an evacuated desiccator, but even after 120 hours some minicores were still losing weight, perhaps because of the slow release of adsorbed water from clay minerals in the rocks. In these cases there is an unknown, though small systematic error in the values of porosity and grain density.

The minicores were weighed on a Centogram Balance and because of the motion of the ship the reproducibility of a single weighing was found to be $\pm 0.02 \mathrm{~g}$. This introduces rms errors into typical values as follows: \pm 0.003 in porosity of $0.03, \pm 0.009$ in wet bulk density of $3.00 \mathrm{~g} / \mathrm{cm}^{3}$, and \pm 0.013 in grain density of 3.00 . Porosity is defined as the ratio of volume of water which can be lost from the specimen by drying at $70^{\circ} \mathrm{C}$ to volume of specimen, so the failure to achieve constant weight will introduce a further systematic

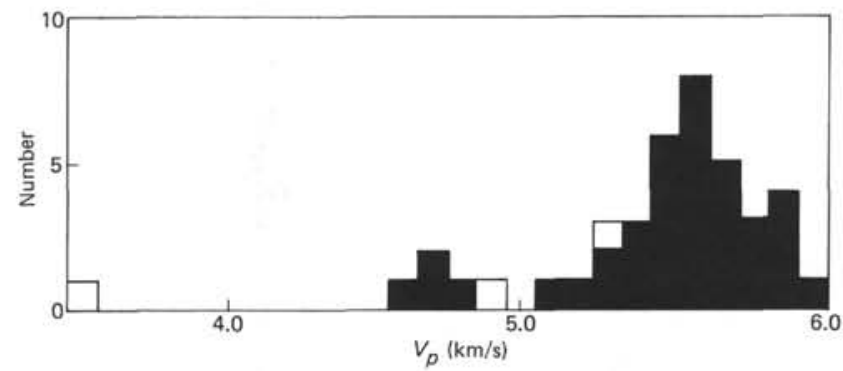

Figure 1. Histogram of mean compressional wave velocities, $V_{p}$, measured at atmospheric pressure in 41 rocks from Hole 396B. Filled squares represent basaltic rocks, open squares non-basaltic.

error. Additional errors may be introduced by surface water when weighing in air. In general the tabulated porosities (in per cent) are considered to be reliable to better than \pm 0.5 per cent absolute and densities to $\pm 0.02 \mathrm{~g} / \mathrm{cm}^{3}$ which is sufficiently accurate for our purpose.

Seismic velocity measurements were made at atmospheric pressure in the Hamilton Frame installed on board (Boyce, 1973). The minicore is placed between two transducers a known distance apart and the time taken for a pulse of $4 \times 10^{5}$ $\mathrm{Hz}$ sound to traverse it is measured using a variable delay oscilloscope. The apparatus was calibrated on two occasions by measuring the time delay caused by transmitting through various lengths of deionized water at known temperature in which the velocity of sound is known. The longitudinal compacting pressure applied to the minicore by the transducers, which tends to increase the measured velocity (Tocher, 1957), is unknown but negligible. Resetting the Hamilton Frame on a rock sample giving a sound arrival of average strength suggests that the repeatability of the time delay measurement is about $\pm 0.02 \mu \mathrm{sec}$ and that of the micrometer gauge about $\pm 0.01 \mathrm{~mm}$, giving for an expected repeatability of a typical velocity.

$$
\mathrm{V}_{p}=5.50 \pm 0.03 \mathrm{~km} / \mathrm{s}(\mathrm{rms}) .
$$

However, velocities have been measured in three perpendicular directions in almost all of the samples obtained on this leg. The results (rounded off to one place of decimals) are presented in Table 1. Examination of these figures, by plotting velocity measured parallel to $z$ against the extreme value, maximum or minimum, measured parallel to $x$ or $y$, reveals no clear evidence of anisotropy of velocity; and if there is no anisotropy then each velocity measurement is an approximation to the mean velocity of the specimen, $\mathrm{V}_{p}$. The figures reveal departures from the mean which in 23 per cent of the cases exceed $0.1 \mathrm{~km} / \mathrm{s}$. Since this is greatly in excess of the 
TABLE 1

Compressional Wave Velocities, Porosity, and Density of Basement Rocks From Hole 396B

\begin{tabular}{|c|c|c|c|c|c|c|c|c|}
\hline $\begin{array}{c}\text { Sample } \\
\text { (Interval in cm) }\end{array}$ & Rock Type-Remarks & $\| Z$ & $\begin{array}{c}\mathrm{V}_{\mathrm{p}} \\
(\mathrm{km} / \mathrm{sec}) \\
Y\end{array}$ & $X$ & $\begin{array}{l}\text { Porosity } \\
\text { (\%) }\end{array}$ & $\begin{array}{l}\text { Wet Bulk } \\
\text { Density } \\
\left(\mathrm{mg} / \mathrm{m}^{3}\right)\end{array}$ & $\begin{array}{c}\text { Grain } \\
\text { Density } \\
\left(\mathrm{mg} / \mathrm{m}^{3}\right)\end{array}$ & $\begin{array}{c}\bar{V}_{p} \\
(\mathrm{~km} / \mathrm{sec})\end{array}$ \\
\hline $4-1,60-62$ & Palagonitized sideromelane breccia & 3.4 & 3.6 & 3.4 & $35.0^{\mathrm{a}}$ & 1.92 & $2.40^{\mathrm{a}}$ & $3.5^{\mathrm{b}}$ \\
\hline $4-1,88-90$ & Fresh basalt & 6.0 & 6.0 & 5.8 & $7.0^{\mathrm{a}}$ & 2.72 & $2.85^{\mathrm{a}}$ & 5.9 \\
\hline $5-1,135-137$ & Carbonate-cemented basalt breccia & 4.9 & 4.8 & - & 14.0 & 2.52 & 2.77 & $4.9^{b}$ \\
\hline $5-2,38-40$ & Basalt pillow with glass & 5.9 & 5.9 & 6.0 & $5.0^{\mathrm{a}}$ & 2.75 & $2.85^{\mathrm{a}}$ & 5.9 \\
\hline $6-1,66-68$ & Fresh basalt & 5.6 & 5.6 & 5.6 & $2.1^{\mathrm{a}}$ & 2.86 & $2.90^{\mathrm{a}}$ & 5.6 \\
\hline $7-1,110-112$ & Moderately altered basalt, vesicular & 5.5 & 5.5 & 5.5 & 3.5 & 2.82 & 2.89 & 5.5 \\
\hline $7-2,8-10$ & Moderately altered basalt & 4.7 & 4.7 & 4.8 & 9.9 & 2.76 & 2.96 & 4.7 \\
\hline $7-3,25-27$ & Moderately altered basalt & 4.4 & 4.6 & 4.7 & 15.3 & 2.67 & 2.98 & 4.6 \\
\hline $8-1,6-8$ & Vesicular basalt & 5.5 & 5.5 & 5.7 & 7.0 & 2.82 & 2.96 & 5.6 \\
\hline $8-2,34-36$ & Pillow with filled vesicles & - & - & 6.0 & 2.5 & 2.88 & 2.93 & $(6.0)$ \\
\hline $9-2,29-31$ & Massive basalt with filled veins & 5.7 & 5.3 & 5.7 & $6.5^{\mathrm{a}}$ & 2.78 & $2.90^{\mathrm{a}}$ & 5.6 \\
\hline $10-1,109-111$ & Fresh basalt, a few fine vesicles & 5.4 & 5.5 & 5.4 & 0.8 & 2.87 & 2.89 & 5.4 \\
\hline $10-2,59-61$ & Fresh basalt, sparsely phyric & 5.6 & 5.7 & 5.7 & 3.4 & 2.87 & 2.94 & 5.7 \\
\hline $11-2,52-54$ & Sparsely phyric fine grained basalt & 5.9 & 5.4 & 5.4 & 4.7 & 2.84 & 2.93 & 5,6 \\
\hline $12-1,35-37$ & Pillow rind; filled vesicles & 5.3 & 5.0 & 5.0 & 8.2 & 2.76 & 2.92 & 5.1 \\
\hline $13-2,8-10$ & Hard fine grained limestone & 5.3 & 5.4 & 5.3 & 5.5 & 2.52 & 2.61 & $5.3^{b}$ \\
\hline $13-2,89-91$ & Fine-grained basalt vesicles filled & 5.5 & 5.6 & 5.6 & - & 2.72 & - & 5.6 \\
\hline $14-1,110-112$ & Pillow basalt & 5.4 & 5.5 & 5.6 & 4.5 & 2.70 & 2.78 & 5.5 \\
\hline $14-2,80-82$ & Massive basalt & 5.8 & 5.7 & 5.7 & - & 2.74 & - & 5.7 \\
\hline $14-3,58-60$ & Sparsely phyric basalt & 5.9 & 5.9 & 5.7 & 4.6 & 2.72 & 2.81 & 5.8 \\
\hline $15-3,69-71$ & Fine-grained dolerite & 5.5 & 5.5 & 5.4 & - & 2.69 & - & 5.5 \\
\hline $15-5,30-32$ & Sparsely phyric fine grained dolerite & 5.9 & 5.9 & 5.8 & 2.0 & 2.74 & 2.78 & 5.9 \\
\hline $16-1,130-132$ & Altered phyric basalt, filled vesicles & 4.8 & 4.7 & 4.7 & 12.6 & 2.53 & 2.76 & 4.7 \\
\hline $16-2,68-70$ & Altered phyric basalt, filled vesicles & 5.6 & 5.6 & 5.6 & - & 2.73 & - & 5.6 \\
\hline $16-5,79-81$ & Phyric basalt & 5.9 & 5.8 & 5.7 & 4.3 & 2.70 & 2.77 & 5.8 \\
\hline $17-1,69-71$ & Altered phyric basalt & 5.2 & 5.2 & 5.2 & - & 2.64 & - & 5.2 \\
\hline $17-2,36-38$ & Altered phyric basalt, filled vesicles & 5.5 & 5.5 & 5.5 & 4.8 & 2.68 & 2.76 & 5.5 \\
\hline $17-3,95-97$ & Altered phyric basalt, filled vesicles & 4.8 & 4.8 & 4.7 & 13.4 & 2.52 & 2.76 & 4.8 \\
\hline $18-1,94-96$ & Basalt & 6.0 & 6.0 & 5.7 & 1.8 & 2.72 & 2.75 & 5.9 \\
\hline $20-1,5-7$ & Phyric basalt & 5.7 & 5.6 & 5.9 & 4.0 & 2.84 & 2.92 & 5.7 \\
\hline $20-2,14-16$ & Olivine plag. phyric basalt & 5.8 & 5.9 & 5.6 & 4.6 & 2.82 & 2.91 & 5.8 \\
\hline $20-3,142-144$ & Altered phyric basalt & 5.4 & 5.4 & 5.7 & 3.6 & 2.80 & 2.87 & 5.5 \\
\hline $20-4,21-23$ & Altered phyric basalt & 5.3 & 5.3 & 5.4 & 5.0 & 2.80 & 2.89 & 5.3 \\
\hline $20-5,96-98$ & Phyric basalt; fresher & 5.6 & 5.6 & 5.7 & 3.2 & 2.84 & 2.90 & 5.6 \\
\hline $21-2,8-10$ & Plag. ol. phyric basalt & 5.5 & 5.5 & 5.5 & 4.6 & 2.79 & 2.88 & 5.5 \\
\hline $22-1,45-47$ & Altered phyric basalt & 5.5 & 5.5 & 5.1 & 3.5 & 2.83 & 2.89 & 5.4 \\
\hline $22-2,21-23$ & Altered phyric basalt & 5.6 & 5.6 & 5.6 & 2.8 & 2.81 & 2.86 & 5.6 \\
\hline $22-4,55-57$ & Phyric basalt, vesicular & 5.4 & 5.4 & 5.3 & 5.0 & 2.81 & 2.91 & 5.4 \\
\hline $24-1,62-63$ & Fresh massive vesicular basalt & 5.5 & 5.7 & $6.0^{\mathrm{c}}$ & 3.8 & 2.83 & 2.90 & 5.7 \\
\hline $26-1,3-5$ & No minicore cut; glassy margin & & $\mathrm{c} 5.3$ & - & - & - & - & (5.3) \\
\hline $32-1,85-87$ & Phyric basalt & 5.7 & 5.6 & 5.8 & - & 2.84 & - & 5.7 \\
\hline
\end{tabular}

${ }^{\mathrm{a}}$ Specimen still losing weight after 120 hours drying in a heated dessicator.

Non-basaltic rock.

Not oriented.

anticipated experimental error, one must regard it as reflecting real variations in the velocity with which this $4 \times 10^{5} \mathrm{~Hz}$ pulse of sound traverses adjacent areas of rock. This conclusion is an accord with those of other similar measurements: for this reason the velocities have been tabulated only to the nearest $0.1 \mathrm{~km} / \mathrm{s}$.

\section{RESULTS}

The results of measurements of velocity, density, and porosity on 40 minicores of the basaltic rocks from Hole 396B are presented in Table 1 and a histogram of velocities appears as Figure 1.

\section{DISCUSSION}

It is clear from the descriptions of the rocks (Chapter 2, this volume) and from the appearance of the minicores, that the most obviously altered rocks have the lowest velocities. The tabulated figures give no clear evidence of anisotropy: the velocity in a vertical direction $(z)$ is not consistently either larger or smaller than that in either horizontal direction.

It is of interest to seek for correlation between physical properties and the lava units defined by petrography, chemistry, and magnetics. Lithologic Unit 1 extends from 150 to 222 meters below the sea floor (Cores 4 to 13 ); Unit 2 extends from 222 to 235 meters (Cores 13 to 15); Unit 3 extends from 235 to 244 meters (Core 15); and Unit 4 extends from 244 to 315 meters (Cores 16 to 22). Chemical unit B1 comprises Cores 16 to 18 and unit B2 comprises Cores 19 to 22 . Inspection of the values of grain density in Table 1 shows that the basaltic specimens fall into two groups: those from Cores 4 to 12 , and 19 onwards, have grain densities greater than $2.85 \mathrm{~g} / \mathrm{cm}^{3}$ while those from Cores 13 to 18 have grain densities less than $2.81 \mathrm{~g} / \mathrm{cm}^{3}$. A bar diagram was drawn showing measured velocities plotted against specimen num- 
bers. Lithologic Unit 1 has widely scattered velocities ranging from 4.5 to $6.0 \mathrm{~km} / \mathrm{s}$. Units 2 and 3, apart from the first sample (396B-13-2, $8 \mathrm{~cm}$ ), which is limestone, form a consistent block with velocity close to $5.6 \mathrm{~km} / \mathrm{s}$. Unit 4 falls in two groups: samples from Cores 16 and 17 , for which alteration is stressed in the site report (see Chapter 2, this volume), have lower and more variable velocities; the remainder have more consistent and higher velocities, about $5.7 \mathrm{~km} / \mathrm{s}$. There are not enough measurements to characterize the other units.

Figure 2 is a plot of velocity against wet bulk density. It illustrates the well-known correlation between the two quantities (Ludwig, et al., 1970; Christensen and Salisbury, 1975). It also illustrates the division of the specimens into two groups on the basis of their grain densities. The anticipated linear relations were also indicated by plots (not shown here) of velocity against porosity and of wet bulk density against porosity.

The histogram of velocities (Figure 1) indicates that the most commonly occurring value is $5.6 \mathrm{~km} / \mathrm{s}$; the mean measured velocity in the basaltic rocks is $5.5 \mathrm{~km} / \mathrm{s}$. No one should believe that this is a measurement of the mean seismic velocity in the rocks penetrated by the drill. The measurements were made in the Hamilton Frame at 1 atmosphere, at $25^{\circ} \mathrm{C}$, and using negligible longitudinal compacting stress. If there are any cracks at all, either intercrystal gaps or open shrinkage cracks, their effect will dominate the measured velocity (Birch, 1961; Wyllie et al., 1958). When the rocks were in place under the sea floor, the compacting pressure tending to close the cracks did not exceed $0.1 \mathrm{kbar}\left(10 \mathrm{MN} / \mathrm{m}^{2}\right)$ even at the maximum depth that the drill penetrated ( 150 meters of sediment and 255 meters of basement rocks). Experience suggests that this pressure is unlikely to increase the velocity over that measured at 1 atmosphere by more than a few per cent and that this increase will be to some extent compensated by the decrease in temperature. (See for example, Matthews, 1971, or Christensen, 1972). In this case the compacting pressure under the sea bed is the lithostatic pressure, given by the product of dry density, gravitational acceleration, and thickness. In the absence of an impermeable layer the hydrostatic pressure $\left(0.45 \mathrm{kbar}, 45 \mathrm{MN} / \mathrm{m}^{2}\right.$, at the bottom of 4465 $\mathrm{m}$ of water) can be neglected because it does not tend to close the cracks since the water is able to enter them (any more than it would close the holes in a bath sponge at the bottom of the sea), and because its effect on the velocity of sound in the individual mineral crystals within the rock framework is much smaller than the efect of the cracks. Thus, as the penetration was so small, it is possible to do without laboratory measurements of sound velocities made on shore under high compacting pressures. One might add that in the laboratory studies are made of the time required for a pulse of high frequency sound (often about $1 \mathrm{MHz}$, wavelength about $5 \mathrm{~mm}$ ) to traverse a jacketed cylinder of water-saturated rock subjected to a known external confining pressure of oil and in which the saturating pore water pressure inside the jacket is maintained at a known value, often 1 atmosphere. As the differential pressure increases from 0 to $1.5 \mathrm{kbar}$, equivalent to the lithostatic pressure at the oceanic Moho, the velocity increases considerably (up to 30 per cent) due largely to progressive closing of the small cracks. Such experiments can only provide a clue to the effect of pressure on seismic velocity in rocks underground where the velocity is measured

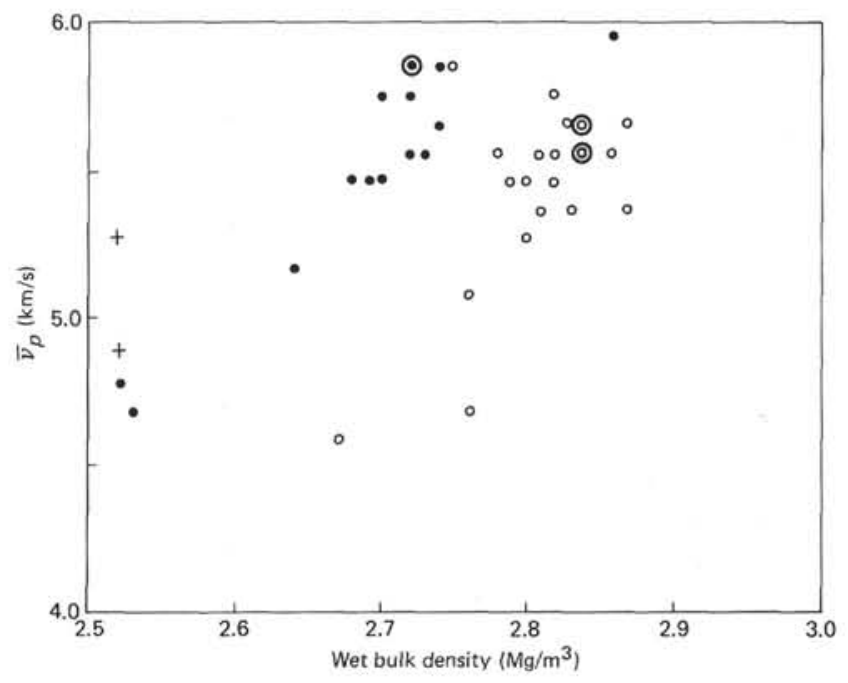

Figure 2. Mean velocity, $\bar{V}_{p}$, plotted against wet bulk density. Plus signs represent values from non-basaltic rocks and filled circles distinguish values from specimens taken from Cores 13 to 18 inclusive. Rings around the symbols indicate a second identical value.

at much lower frequencies (about $10 \mathrm{~Hz}$, wavelength about $0.5 \mathrm{~km})$ and the overburden pressure has to close relatively wide joints and fissures.

Much more serious is the bias in the sampling. In order to be able to cut a minicore from the rocks in the core, only the least cracked pieces could be drilled; even then, several of them broke up while being drilled. By selecting specimens without obvious cracks the sample is necessarily biased towards higher velocity. Moreover it is important to remember that only some 20 per cent of the rocks traversed by the drill were recovered in the cores. This in itself probably produces a sample biased towards the harder, more cohesive units that have higher velocities. So there should be no difficulty reconciling the relatively high velocities listed in Table 1 with the much lower velocities obtained in the Schlumberger velocity log (Kirkpatrick, this volume) or commonly obtained by seismic refraction experiments, particularly when we take into account the clear evidence of fracturing and fissuring that has been obtained by drilling at Hole 396B, on previous legs, and in the FAMOUS area.

\section{ACKNOWLEDGMENTS}

The minicores were weighed and dried on board by Richard Myers. The Oblique Seismic Experiment was funded by the Natural Environment Research Council, London, under Grant GR3/2864 to the University of Cambridge. I thank Dr. Carol Williams for reviewing this paper.

\section{REFERENCES}

Birch, F., 1961. The velocity of compressional waves in rocks to 10 kilobars, Part 2, J. Geophys. Res., v. 66, p. 2199-2224.

Boyce, R. E., 1973. Physical Properties - Methods. In Edgar, N. T., Saunders, J. B., et al. Initial Reports of the Deep Sea Drilling Project, v. 15: Washington (U.S. Government Printing Office).

Christensen, N. I., 1972. Compressional and shear wave velocities at pressures to 10 kilobars for basalts from the East Pacific Rise, Geophys. J. Roy. Astron. Soc., v. 28, p. 425-429. 
Christensen, N. I. and Salisbury, M. H., 1975. Structure and constitution of the lower oceanic crust, Rev. Geophys. Space Phys., v. 13 , p. $57-86$

Ludwig, W. J., Nafe, J. E., and Drake, C. L., 1970. Seismic Refraction. In Maxwell, A. E., (Ed.), The Sea, v. 4, pt. 1: New York (Wiley-Interscience), p. 53-84.

Matthews, D. H., 1971. Altered basalts from swallow bank, an abyssal hill in the NE Atlantic, and from a nearby seamount. Phil. Trans. Roy. Soc. London, ser. A., v. 268, p. 551-571. Tocher, D., 1957. Anisotropy in rocks under simple compression, Trans. Am. Geophys. Un., v. 38, p. 89-94.

Wyllie, M. R. J., Gregory, A. R., and Gardner, G. H. F., 1958. An experimental investigation of factors affecting elastic wave velocities in porous media, Geophysics, v. 23, p. 459-493. 